\title{
Cytotoxicity assays as tools to assess water quality in the Sinos River basin
}

\author{
Trintinaglia, L. ${ }^{a}$, Bianchi, E. ${ }^{b}$, Silva, LB. ${ }^{c}$, Nascimento, CA. ${ }^{d}$, Spilki, FR. ${ }^{c}$ and Ziulkoski, AL. ${ }^{c *}$ \\ anstituto de Ciências da Saúde, Universidade Feevale, RS-239, 2755, CEP 93525-075, Novo Hamburgo, RS, Brazil \\ bUniversidade Feevale, RS-239, 2755, CEP 93525-075, Novo Hamburgo, RS, Brazil \\ 'Programa de Pós-Graduação em Qualidade Ambiental, Instituto de Ciências da Saúde, \\ Universidade Feevale, RS-239, 2755, CEP 93525-075, Novo Hamburgo, RS, Brazil \\ dPrograma de Pós-Graduação em Qualidade Ambiental, Instituto de Ciências Exatas e Tecnológicas, \\ Universidade Feevale, RS-239, 2755, CEP 93525-075, Novo Hamburgo, RS, Brazil \\ *e-mail: analuiza@feevale.br
}

Received: May 24, 2013 - Accepted: September 09, 2013 - Distributed: May 31, 2015

(With 2 figures)

\begin{abstract}
Cytotoxicity assays using cell cultures may be an alternative to assess biological toxicity of surface waters and may help to improve the control of water quality. This study compared two methods to prepare culture media for the exposure of Hep-2 cells to water samples collected from the Rolante River, an important affluent of the Sinos River. The toxicity was evaluated using the MTT and neutral red assays. Two methods were used to prepare culture media. In method 1, the sample was diluted at $1: 1,1: 10,1: 100,1: 1000,1: 10.000(\mathrm{v} / \mathrm{v}$, sample/medium $)$ in a standard culture medium; in method 2, water samples were used as the solvent for the culture medium, which was prepared at concentrations of 100 , $80,60,40$ and $20 \%$. Semi-confluent cultures were then exposed to the media test for 24 hours, and cytotoxicity was determined immediately using the MTT and NR assays. Mitochondrial activity (MTT) was significantly lower at all concentrations in both methods, except at 1:1000 in method 1. However, the lysosome viability (NR) results revealed cytotoxicity only in the 1:1 sample of method 1 . Both culture preparation methods were efficient and sensitive to the MTT assay, but method 2 seemed to be more adequate for the NR assay. The Rolante River has cytotoxic contaminants to Hep-2 cells, which may be one of the explanations for the poor water quality of the Sinos River basin.
\end{abstract}

Keywords: cytotoxicity, Sinos River basin, samples preparation.

\section{Ensaios de citotoxicidade como ferramentas para avaliar a qualidade da água da bacia do Rio do Sinos}

\section{Resumo}

Os ensaios de citotoxicidade utilizando culturas de células constituem uma alternativa para avaliar a toxicidade biológica de águas de superfície e podem auxiliar no controle da qualidade da água. Este estudo comparou dois métodos de preparação dos meios de cultura com amostras de água coletadas no rio Rolante, um importante afluente do Rio dos Sinos, para a exposição de células Hep-2. A toxicidade foi avaliada usando os ensaios do MTT e do vermelho neutro (VN). Dois métodos foram utilizados para preparar os meios de cultura. No método 1, a amostra foi diluída a 1:1, 1:10, 1:100, 1:1000 e 1:10.000 (v/v, amostra/ meio de cultivo) em um meio de cultura padrão; no método 2, as amostras de água foram utilizados como solventes para o meio de cultura, o qual foi preparado em concentração de $100 \%$ e nas diluições de 80, 60, 40 e 20\%. Culturas semi-confluentes foram então expostas aos meios teste durante 24 horas, e a citotoxicidade foi determinada imediatamente usando os ensaios MTT e VN. A atividade mitocondrial (MTT) foi significativamente menor em todas as concentrações em ambos os métodos, exceto na diluição 1:1000 do método 1 . No entanto, os resultados de viabilidade lisossomal (VN) revelaram citotoxicidade apenas no na diluição 1:1 do método 1. Ambos os métodos de preparação do meio cultura foram eficientes e sensíveis para o ensaio do MTT, mas o método 2 foi mais adequado para o ensaio do VN. O rio Rolante possui contaminantes citotóxicos para as células Hep-2, o que pode ser uma das explicações para a baixa qualidade da água da Bacia do Rio dos Sinos.

Palavras chave: citotoxicidade, bacia do Rio do Sinos, preparação de amostras. 


\section{Introduction}

Surface waters, such as in rivers and lakes, are often exposed to household, industrial and agricultural contaminants (Ohe et al., 2004; Pellacani et al., 2006; Žegura et al., 2009; Lemos et al., 2012), such as pesticides, heavy metals and household cleaning products that contribute to toxicity (Pereira et al., 2007; Vargas et al., 2008).

The Sinos River basin (SRB) in the state of Rio Grande do Sul, Brazil, covers thirty two municipalities (Costa and Schulz, 2010; Figueiredo et al., 2010). The main anthropogenic factors in the area are the agricultural activity in the upper reach, the leather and footwear industry and the increase of the population density in the middle reach, and a high population density and the presence of leather and footwear industry, metallurgy and petrochemical plants in the lower reach (Bieger et al., 2010; Figueiredo et al., 2010; FEPAM, 2012; Nunes et al., 2011).

Surface waters are usually monitored by means of physical and chemical analyses (Pellacani et al., 2006). However, these methods only detect and measure the concentration of toxic substances; they cannot estimate the effects on the biota and do not assess actual environmental risks. Therefore, toxicity tests may be a useful tool to complete the assessment of surface water quality (Georgudaki et al., 2003; Goulart and Callisto, 2003; Costa et al, 2008).

Toxicity tests, widely used for in vitro toxicology, allow the direct or indirect contact of the sample studied with a cell culture and thus, it is possible to assess cell changes produced according to different mechanisms (Rogero et al., 2003; Freshney, 2005; Khatibisepehr et al., 2011). Some of the most used assays are the neutral red (NR) uptake by lysosomes and the mitochondrial activity test using MTT (Fotakis and Timbrell, 2006). They produce significant data in a short period of time, have high sensitivity and reproducibility and low costs (Rogero et al., 2003), which suggests that cytotoxicity assays in cell cultures may be used to assess the ecotoxicological potential of environmental samples (Suares Rocha et al., 2010).

Cytotoxicity assays may also be used to detect early damage, since water contaminants have two main effects on cells: toxic effects, which lead to cell death; and proliferative effects, which may be associated with carcinogenic effects on the biota involved (Suares Rocha et al., 2010). The presence of contaminants may result in morphological and cell adhesion changes, abnormalities in the cell cycle and in DNA (Khatibisepehr et al, 2011), and enzyme changes, particularly those associated with biotransformation (Suares Rocha et al., 2010).

Considering the little data available and the need to assess the toxicity of water in Sinos River basin, the present study compared two methods to prepare culture media for exposure of Hep-2 cells to a water sample collected from the Rolante River, an important affluent of the Sinos River and evaluated water toxicity using the MTT and NR tests.

\section{Methods}

\subsection{Sampling and sample collection}

Surface water samples were collected in February 2012 at the water intake sites of the Rolante River, in the city of Rolante (29³9'25.56”S, 50³4'28.19”W), Brazil. According to the CETESB (1988) collection protocols, 100 millilitres of water were collected in previously sterilized containers of an adequate size. After collection, samples were placed into a thermal recipient and taken to the Laboratory of Molecular Microbiology at the Universidade Feevale.

\subsection{Preparation of samples and media test}

Samples were filtered using $0.22-\mu \mathrm{L}$ filters and then two methods were used to prepare the Dulbecco's modified Eagle medium (DMEM, Sigma ${ }^{\circledR}$ ) containing the Rolante River water sample.

Method 1: The water collected from the sampling sites was mixed with standard culture medium supplemented with $10 \%$ of fetal bovine serum (FBS, Cultilab ${ }^{\circledR}$ ), $10,000 \mathrm{U} / \mathrm{mL}$ of penicillin and $10 \mathrm{ng} / \mathrm{mL}$ of streptomycin $\left(\right.$ Sigma $\left.^{\circledR}\right)$. Samples at 1:1, 1:10, 1:100, 1:1000 and $1: 10000$ (v/v, sample/medium) were prepared by gradual dilution of the sample in standard culture medium.

Method 2: water from the sampling sites was used as the solvent for the culture medium; $0.3 \mathrm{~g}$ of DMEM low glucose $\left(\right.$ Sigma $\left.^{\circledR}\right), 0.066$ g sodium bicarbonate and $0.063 \mathrm{~g}$ Hepes buffer $\left(\right.$ Sigma $\left.^{\circledR}\right)$ were dissolved in $27 \mathrm{~mL}$ of surface water. The $\mathrm{pH}$ was adjusted to 7.4 , and $3 \mathrm{~mL}$ of FBS were added to complete the final volume of $30 \mathrm{~mL}$ of medium with $10 \%$ of FBS. The samples were filtered in a $0.22 \mu \mathrm{m}$ filter under sterile conditions, and $10,000 \mathrm{U} / \mathrm{mL}$ of penicillin and $10 \mathrm{mg} / \mathrm{mL}$ of streptomycin $\left(\right.$ Sigma $\left.{ }^{\circledR}\right)$ were added. At the end of the process, a culture medium with the maximum water sample concentration of the river was obtained and classified as $100 \%$ concentration. Culture media were then prepared at concentrations of $80 \%, 60 \%, 40 \%$ and $20 \%$ by mixing it with the standard culture medium.

\subsection{Cell culture and treatment}

Epithelioid Hep-2 cells were obtained from a cell bank in Rio de Janeiro, Brazil. These cells were isolated from cysts formed in mice that had received injections of human larynx epidermoid carcinoma. This cell line, derived from mouse responses, was chosen primarily because of its wide application in genotoxicity studies and its sensitivity to xenobiotic agents (Amaro et al., 2009).

Cells were grown in DMEM supplemented with $10 \% \mathrm{FBS}, 10,000 \mathrm{U} / \mathrm{mL}$ of penicillin and $10 \mathrm{mg} / \mathrm{mL}$ of streptomycin. The culture was maintained at $37^{\circ} \mathrm{C}$ in a humid atmosphere at $5 \%$ of $\mathrm{CO}_{2}$ and a half-open system, and trypsinization was used for cell maintenance.

For exposure to surface waters, cells were seeded at a rate of $2 \times 10^{4}$ cells/well in a 96 -well polystyrene microplate. After the cultures reached semiconfluence, 
culture medium was replaced with the media prepared using either method 1 or 2 at different concentrations, and the cells were exposed for 24 hours. Cells cultured in standard conditions were used as negative control. All assays were repeated in quadruplicates in two independent experiments that had the same result profile.

\subsection{Cytotoxicity assay using MTT reduction}

In order to evaluate cytotoxicity using the mitochondrial activity parameter, a 3-[4,5-dimethylthiazol-2-yl]-2,5diphenyltetrazolium bromide (MTT) assay was used as described by Mosmann (1983). After exposure for 24 hours, $20 \mu \mathrm{L}$ of MTT $1.67 \mathrm{mg} / \mathrm{mL}$ was added, and the plates were incubated for 2 hours. After incubation, the medium was removed by inversion, and $200 \mu \mathrm{L}$ of dimethyl sulfoxide (DMSO) was added to each well for solubilisation. All samples were transferred to a 96-well plate and absorbance was measured at $540 \mathrm{~nm}$ with a microplate spectrophotometer.

\subsection{Cytotoxicity assay by neutral red incorporation}

The neutral red (NR) incorporation method, described by Borenfreund and Puerner (1985), was used to evaluate cytotoxicity through the lysosome viability. After exposure for 24 hours, the culture medium was removed and $200 \mu \mathrm{L}$ of DMEM without serum and containing $50 \mu \mathrm{g} / \mathrm{mL}$ of NR was added to each well. After three hours of incubation at $37^{\circ} \mathrm{C}$ in humid atmosphere at $5 \%$ of $\mathrm{CO}_{2}$, the medium was removed and the cells were washed with a buffered saline solution (PBS) followed by another washing with a fixative solution $\left(1 \% \mathrm{CaCl}_{2}\right.$ in $0.5 \%$ formaldehyde). After discarding by inversion, $200 \mu \mathrm{L}$ of $1 \%$ acetic acid in $50 \%$ ethanol was added for the solubilisation of the dye. The samples were gently shaken for 10 minutes for full dissolution. All samples were transferred to a 96-well plate and the absorbance was measured at $540 \mathrm{~nm}$ with a microplate spectrophotometer.

\subsection{Statistical analysis}

One-way ANOVA and the Duncan post-test were used for statistical analysis with the Statistical Package for the Social Sciences (SPSS) 15.0 for Windows. The level of significance was set at $\mathrm{p}<0.05$.

\section{Results}

Mitochondrial activity, assessed using the MTT assay (Figure 1), was significantly lower than in controls in all the culture media prepared using method 1 , except for the 1:1000 medium. In method 2 , all the concentrations ( $20 \%$ to $100 \%$ ) had a significantly lower mitochondrial activity than in the control group.

The results of cytotoxicity assays using NR (Figure 2), which assessed lysosome viability, showed a decrease of viable cells in the 1:1 medium from method 1 . The culture media prepared using method 2 did not show any significant reduction of NR results.

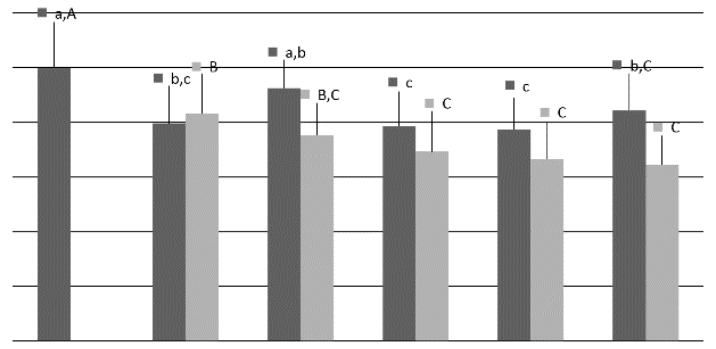

Figure 1. Cytotoxicity of water in the Sinos River basin using Hep-2 cells and the MTT assay. MTT after exposure to the Rolante River water sample for 24 hours - black column: method 1; gray column: method 2. Representative results of two individual experiments performed in quadruplicate, each bar represents media $\pm \mathrm{SD}$. One-way ANOVA and Duncan post-test were used for statistical analyses $(\mathrm{p}<0.05)$. Different letters indicate statistically different results.

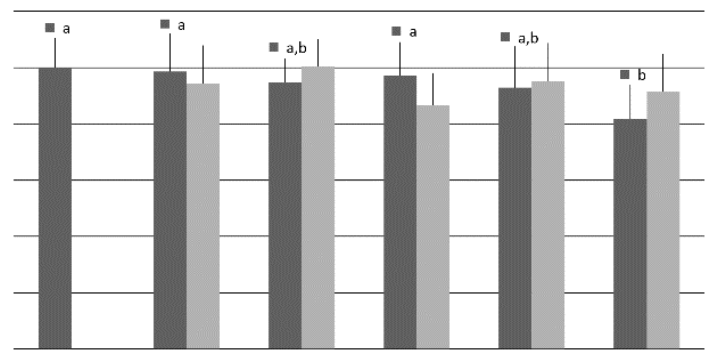

Figure 2. Cytotoxicity of water in the Sinos River basin using Hep-2 cells and the neutral red assay NR after exposure to the Rolante water for 24 hours - black column: method 1; gray column: method 2. Representative results of two individual experiments performed in quadruplicate, each bar represents media $\pm \mathrm{SD}$. One-way ANOVA and Duncan post-test were used for statistical analyses $(\mathrm{p}<0.05)$. Different letters indicate statistically different results.

\section{Discussion}

The exposure of Hep-2 cells to surface water from the Rolante River for 24 hours demonstrated significant changes in cytotoxicity according to the mitochondrial activity assay. Results were lower than those found for controls in all the tests for medium prepared using both methods, except for the 1:1000 medium using method 1. However, the lysosome viability assay demonstrated changes only in the 1:1 medium prepared using method 1 .

Studies suggest that MTT is an economic, rapid, sensitive and specific assay to determine in vitro cytotoxicity, and it is also believed to show the effects of early cytotoxicity (Malich et al., 1997). The test is based on the technique developed by Mosmann (1983), in which a yellow tetrazole water soluble salt, MTT, is reduced to a purple formazan salt by the action of succinate dehydrogenase in mitochondria. The resulting product indicates mitochondrial activity and it is proportional to the number of viable cells (Triglia et al., 1991; Butler, 2004; Freshney, 2005). The NR 
assay was first described by Borenfreund and Puerner in 1985 and it is based on the capacity of a vital soluble dye to cross the plasmatic membrane and accumulate in viable lysosomes (Borenfreund et al., 1988; Triglia et al., 1991).

Both assays use colorimetric measurements to define the number of viable cells after exposure to agents that may be toxic. However, different cytotoxicity assays may have different results because each assay may assess a different function (Borenfreund et al., 1988). According to Fotakis and Timbrell (2006), who conducted a study with exposures to cadmium to assess four different cytotoxicity assays, the NR and MTT assays had a higher sensitivity for the detection of toxicity than lactate dehydrogenase (LDH) and protein content assays. Moreover, assays involving mitochondrial activity may demonstrate early toxicity signs when compared with the NR assay because lysosome activity might be associated with the possibility of cell death, whereas mitochondrial changes may not necessarily lead to death, but may indicate cell and DNA damage (Fotakis and Timbrell, 2006). Therefore, the comparison of results in our study suggests that the MTT assay is more sensitive than the NR assay since more changes in mitochondrial functionality were observed than lysosomal viability with the same samples.

Studies on water toxicity, such as the one conducted by Žegura et al. (2006), which analysed mitochondrial activity in water from different sources, including surface water, found elevated toxicity in two collecting sites for river samples. The cell line used was Hep-G2, which was exposed for 20 hours to culture medium containing $40 \%$ of water from the sampling sites. Their results suggested that the MTT assay was sensitive for the detection of cytotoxic changes in water and the mixture percentage may be successfully used. Other studies conducted with the NR assay and Hep-G2 cells, such as the one conducted by Marabini et al. (2007), the exposure of cells for 24 hours to treated water samples revealed cytotoxicity in some of the samples evaluated. In a study with other cell lines and waters from the Sinos River basin, Nunes et al. (2011) found cytotoxicity in the samples collected in Canoas, São Leopoldo and Novo Hamburgo cities. They studied water samples from June 2006 using the V79 cell line and the methanol fixation method followed by violet crystal staining, which suggested basin depreciation.

The Rolante collection site is located in the upper reach of the $\mathrm{SRB}$, in a region characterized by the presence of cattle raising and agro-industrial businesses, especially rice, sugarcane and vegetable, activities that use water from the basin for its supply (Lemos et al., 2009; Bieger et al., 2010; Figueiredo et al., 2010; Scalon et al., 2010; FEPAM, 2012). Agribusiness involves the use of pesticides and fertilizers to increase productivity (Carabias Martínez et al., 2000; Cerejeira et al., 2003); therefore, the cytotoxicity found in our study may be associated with the presence of agro-industrial activity. Vargas et al. (2001), using a microsome assay and Salmonella cells, found cytotoxicity and mutagenicity in the analysis of water from a city in the upper reach of the SRB. This effect, according to the authors, may be associated with the presence of contaminants from agro-industry, once the presence of heavy metals in the region was lower than in reference values. Lemos et al. (2009) also found cytotoxicity in water and sediments from the Rolante River using the same assay.

Our study demonstrated that the Hep- 2 cells may be used in environmental monitoring studies, and that both methods used to prepare culture media were efficient and sensitive to MTT. However, method 2 provided more consistent results for the NR assay. Our data also confirmed that the Rolante River, an important affluent of the Sinos River, is contaminated with cytotoxic substances that may compromise the balance of the aquatic biota in this river basin.

\section{Acknowledgements}

The authors thank Conselho Nacional de Desenvolvimento Científico e Tecnológico (CNPq) for grant no. 477784/2011-9, Coordenação de Aperfeiçoamento de Pessoal de Nível Superior (CAPES) for the doctorate grant awarded to one of the authors, and Universidade Feevale for the infrastructure, financial support and undergraduate scholarship for research. FRS is a CNPq researcher.

\section{References}

AMARO, MI., MONASTERIOS, M., AVENDAÑO, M. and CHARRIS, J., 2009. Preliminary evaluation of the toxicity of some synthetic furan derivatives in two cell lines and Artemia salina. Journal of Applied Toxicology: JAT, vol. 29, no. 1, p. 36-41. http://dx.doi.org/10.1002/jat.1379. PMid:18720481

BIEGER, L., CARVALHO, ABP., STRIEDER, MN., MALTCHIK, L. and STENERT, C., 2010. Are the streams of the Sinos River basin of good water quality? Aquatic macroinvertebrates may answer the question. Brazilian Journal of Biology $=$ Revista Brasileira de Biologia, vol. 70, supplement 4, p. 1207-1215. http:// dx.doi.org/10.1590/S1519-69842010000600010. PMid:21225162

BORENFREUND, E. and PUERNER, JA., 1985. Toxicity determined in vitro by morphological alterations and neutral red absorption. Toxicology Letters, vol. 24, no. 2-3, p. 119-124. http://dx.doi.org/10.1016/0378-4274(85)90046-3. PMid:3983963

BORENFREUND, E., BABICH, H. and MARTIN-ALGUACIL, N., 1988. Comparisons of two in vitro cytotoxicity assays-the neutral red (NR) and tetrazolium MTT tests. Toxicology In Vitro: An International Journal Published in Association with BiBRA, vol. 2, no. 1, p. 1-6. http://dx.doi.org/10.1016/0887-2333(88)90030-6. PMid:20702351

BUTLER, M., 2004. Animal cell culture and technology. London: BIOS Scientific Publishers. 244 p. http://dx.doi. org/10.4324/9780203427835.

CARABIAS MARTÍNEZ, R., RODRÍGUEZ GONZALO, E., FERNÁNDEZ LAESPADA, M. and SÁNCHEZ SAN ROMÁN, F., 2000. Evaluation of surface- and ground-water pollution due to herbicides in agricultural areas of Zamora and Salamanca (Spain). Journal of Chromatography A, vol. 869, no. 1-2, p. 471-480. http:// dx.doi.org/10.1016/S0021-9673(99)01188-7. PMid:10720260 
CEREJEIRA, MJ., VIANA, P., BATISTA, S., PEREIRA, T., SILVA, E., VALÉRIO, MJ., SILVA, A., FERREIRA, M. and SILVA-FERNANDES, AM., 2003. Pesticides in Portuguese surface and ground waters. Water Research, vol. 37, no. 5, p. 1055-1063. http://dx.doi.org/10.1016/S0043-1354(01)00462-6. PMid:12553980

Companhia de Tecnologia de Saneamento Ambiental - CETESB, 1988. Guia de coleta e preservação de amostras de água. São Paulo: CETESB. $150 \mathrm{p}$

COSTA, CR., OLIVI, P., BOTTA, CMR. and ESPINDOLA, ELG., 2008. A toxicidade em ambientes aquáticos: discussão e métodos de avaliação. Quimica Nova, vol. 31, no. 7, p. 1820-1830. http:// dx.doi.org/10.1590/S0100-40422008000700038.

COSTA, PF. and SCHULZ, UH., 2010. The fish community as an indicator of biotic integrity of the streams in the Sinos River basin, Brazil. Brazilian Journal of Biology $=$ Revista Brasileira de Biologia, vol. 70, supplement 4, p. 1195-1205. http://dx.doi. org/10.1590/S1519-69842010000600009. PMid:21225161

FIGUEIREDO, JAS., DRUMM, E., RODRIGUES, MAS. and SPILKI, FR., 2010. The Rio dos Sinos watershed: an economic and social space and its interface with environmental status. Brazilian Journal of Biology $=$ Revista Brasileira de Biologia, vol. 70, supplement 4, p. 1131-1136. PMid:21225153.

FOTAKIS, G. and TIMBRELL, JA., 2006. In vitro cytotoxicity assays: comparison of LDH, neutral red, MTT and protein assay in hepatoma cell lines following exposure to cadmium chloride. Toxicology Letters, vol. 160, no. 2, p. 171-177. http://dx.doi. org/10.1016/j.toxlet.2005.07.001. PMid:16111842

FRESHNEY, RI., 2005. Culture of animal cells: a manual of basic technique. Hoboken: Wiley-Liss. 642 p. http://dx.doi. org/10.1002/9780471747598.

Fundação Estadual de Proteção Ambiental Henrique Luiz Roessler -FEPAM, 2012. Qualidade ambiental: Região Hidrográfica do Guaíba. Qualidade das águas da Bacia Hidrográfica do Rio do Sinos. FEPAM. Available from: <http://www.fepam.rs.gov.br/ qualidade/qualidade_sinos/sinos.asp >. Access in: 10 Oct. 2012.

GEORGUDAKI, JI., KANTZARIS, V., KATHARIOS, P., KASPIRIS, P., GEORGIADIS, TH. and MONTESANTOU, B., 2003. An application of different bioindicators for assessing water quality: a case study in the Rivers Alfeios and Pineios (Peloponnisos, Greece). Ecological Indicators, vol. 2, no. 4, p. 345-360. http://dx.doi.org/10.1016/S1470-160X(03)00004-9.

GOULART, MDC. and CALLISTO, M., 2003. Bioindicadores de qualidade de água como ferramenta em estudos de impacto ambiental. Revista da FAPAM, vol. 2, no. 1.

KHATIBISEPEHR, S., HUANG, B., IBRAHIM, F., XING, JZ. and ROA, W., 2011. Data-based modeling and prediction of cytotoxicity induced by contaminants in water resources. Computational Biology and Chemistry, vol. 35, no. 2, p. 69-80. http://dx.doi. org/10.1016/j.compbiolchem.2011.02.001. PMid:21482193

LEMOS, AT., CORONAS, MV., ROCHA, JAV. and VARGAS, VMF., 2012. Mutagenicity of particulate matter fractions in areas under the impact of urban and industrial activities. Chemosphere, vol. 89, no. 9, p. 1126-1134. http://dx.doi.org/10.1016/j. chemosphere.2012.05.100. PMid:22795069

LEMOS, AT., ROSA, DP., ROCHA, JAV. and VARGAS, VMF., 2009. Mutagenicity assessment in a river basin influenced by agricultural, urban and industrial sources. Ecotoxicology and
Environmental Safety, vol. 72, no. 8, p. 2058-2065. http://dx.doi. org/10.1016/j.ecoenv.2009.08.006. PMid:19744711

MALICH, G., MARKOVIC, B. and WINDER, C., 1997. The sensitivity and specificity of the MTS tetrazolium assay for detecting the in vitro cytotoxicity of 20 chemicals using human cell lines. Toxicology, vol. 124, no. 3, p. 179-192. http://dx.doi. org/10.1016/S0300-483X(97)00151-0. PMid:9482120

MARABINI, L., FRIGERIO, S., CHIESARA, E., MAFFEI, F., CANTELLI FORTI, G., HRELIA, P., BUSCHINI, A., MARTINO, A., POLI, P., ROSSI, C. and RADICE, S., 2007. In vitro cytotoxicity and genotoxicity of chlorinated drinking waters sampled along the distribution system of two municipal networks. Mutation Research, vol. 634, no. 1-2, p. 1-13. http://dx.doi.org/10.1016/j. mrgentox.2007.05.017. PMid:17884717

MOSMANN, T., 1983. Rapid colorimetric assay for cellular growth and survival: application to proliferation and cytotoxicity assays. Journal of Immunological Methods, vol. 65, no. 1-2, p. 55-63. http://dx.doi.org/10.1016/0022-1759(83)90303-4. PMid:6606682

NUNES, EA., LEMOS, CT., GAVRONSKI, L., MOREIRA, TN., OLIVEIRA, NCD. and SILVA, J., 2011. Genotoxic assessment on river water using different biological systems. Chemosphere, vol. 84, no. 1, p. 47-53. http://dx.doi.org/10.1016/j. chemosphere.2011.02.085. PMid:21435689

OHE, T., WATANABE, T. and WAKABAYASHI, K., 2004. Mutagens in surface waters: a review. Mutation Research, vol. 567, no. 2-3, p. 109-149. http://dx.doi.org/10.1016/j.mrrev.2004.08.003. PMid:15572284

PELLACANI, C., BUSCHINI, A., FURLINI, M., POLI, P. and ROSSI, C., 2006. A battery of in vivo and in vitro tests useful for genotoxic pollutant detection in surface waters. Aquatic Toxicology, vol. 77, no. 1, p. 1-10. http://dx.doi.org/10.1016/j. aquatox.2005.10.010. PMid:16313981

PEREIRA, TS., ROCHA, JAV., DUCCATTI, A., SILVEIRA, GA., PASTORIZA, TF., BRINGUENTI, L. and VARGAS, VM., 2007. Evaluation of mutagenic activity in supply water at three sites in the state of Rio Grande do Sul, Brazil. Mutation Research, vol. 629, no. 2, p. 71-80. http://dx.doi.org/10.1016/j. mrgentox.2006.12.008. PMid:17409014

ROGERO, SO., LUGÃO, AB., IKEDA, TI. and CRUZ, AS., 2003. Teste in vitro de cytotoxicidade: estudo comparativo entre duas metodologias. Materials Research, vol. 6, no. 3, p. 317-320. http://dx.doi.org/10.1590/S1516-14392003000300003.

SCALON, MC., RECHENMACHER, C., SIEBEL, AM., KAYSER, ML., RODRIGUES, MT., MALUF, SW., RODRIGUES, MAS. and SILVA, LB., 2010. Evaluation of Sinos River water genotoxicity using the comet assay in fish. Brazilian Journal of Biology = Revista Brasileira de Biologia, vol. 70, supplement 4, p. 1217 1222. http://dx.doi.org/10.1590/S1519-69842010000600011. PMid:21225163

SUARES ROCHA, P., AZAB, E., SCHMIDT, B., STORCH, V., HOLLERT, H. and BRAUNBECK, T., 2010. Changes in toxicity and dioxin-like activity of sediments from the Tietê River (São Paulo, Brazil). Ecotoxicology and Environmental Safety, vol. 73, no. 4, p. 550-558. http://dx.doi.org/10.1016/j.ecoenv.2009.12.017. PMid:20074803

TRIGLIA, D., SHERARD BRAA, S., YONAN, C. and NAUGHTON, GK., 1991. Cytotoxicity testing using neutral red and MTT assays on a three-dimensional human skin substrate. Toxicology in Vitro, vol. 5, no. 5-6, p. 573-578. http://dx.doi. org/10.1016/0887-2333(91)90096-V. PMid:20732080 
VARGAS, VMF., MIGLIAVACCA, SB., HORN, RC. and TERRA, NR., 2008. Comparative temporal ecotoxicological study in a river basin influenced by petrochemical industries. The Science of the Total Environment, vol. 392, no. 1, p. 79-92. http://dx.doi. org/10.1016/j.scitotenv.2007.10.043. PMid:18083216

VARGAS, VMF., MIGLIAVACCA, SB., MELO, AC., HORN, RC., GUIDOBONO, RR., FERREIRA, ICS. and PESTANA, MHD., 2001. Genotoxicity assessment in aquatic environments under the influence of heavy metals and organic contaminants.
Mutation Research, vol. 490, no. 2, p. 141-158. http://dx.doi. org/10.1016/S1383-5718(00)00159-5. PMid:11342240

ŽEGURA, B., HEATH, E., CERNOSA, A. and FILIPIC, M., 2009. Combination of in vitro bioassays for the determination of cytotoxic and genotoxic potential of wastewater, surface water and drinking water samples. Chemosphere, vol. 75, no. 11, p. 1453-1460. http://dx.doi.org/10.1016/j.chemosphere.2009.02.041. PMid:19307011 